\title{
Seven spruce species on a mountain site - performance, foliar nutrients, and forest floor properties in stands 20 years old
}

\author{
Ondřej Špulák, \\ Dušan Kacálek, \\ Vratislav Balcar
}

\begin{abstract}
Norway spruce is often considered to have a negative impact on a site, yet it is native to many mountain regions of Europe. The relative influence of Norway spruce on site properties has frequently been compared with that of both broadleaved and other coniferous tree species. In our study, growth, as well as needle, forest floor, and topsoil chemistry were compared between Norway spruce and introduced spruce species (white, black, red, Serbian, Sitka, and blue spruce), all growing on the same, formerly polluted mountain site. There were few differences in needle nutrient status between the introduced spruce species and native Norway spruce. The chemistry of forest floor horizons beneath some of the non-native species showed less acidity and better conditions of the soil sorption complex. There were no significant differences in the nutrient pools, indicating that the influence of the various spruce species on the site was comparable. Given the small differences observed in the various nutritional characteristics, it appears that, under the conditions of the study site, the alternative spruces had substituted for the role of Norway spruce before its recovery in the 2000 s. The six spruces grew quite consistently during 2001-2012, while the mean height of Norway spruce shifted from the lowest $176 \mathrm{~cm} \mathrm{(2001)} \mathrm{to} \mathrm{one} \mathrm{of} \mathrm{the} \mathrm{tallest.} \mathrm{At} 710 \mathrm{~cm} \mathrm{(2012),} \mathrm{its} \mathrm{height} \mathrm{had} \mathrm{become}$ comparable with that of Sitka. The poorest performing were black spruce (due to bark beetle attack) and blue spruce (due to bud blight infestation and decline).
\end{abstract}

Keywords: Spruce, Performance, Foliar Nutrients, Forest Floor, Soil

felling. Therefore, local foresters had to replace it with plantations of other tree species in order to renew forest cover. Both native and introduced woody species thought to be more resistant to the acid pollutants were tested. Among these, other spruce species were of interest to both researchers (Materna 1989, Balcar 1996) and forestry practitioners. The practitioners mostly used blue spruce (Picea pungens Engelm.) to restock the cleared areas in the Ore and Jizera mountains (Slodičák et al. 2008, 2009). Because the pollution has diminished since then (Oulehle et al. 2011, Lomský et al. 2012), native commercial species are planted today. Experimental stands of non-native species nevertheless still exist within the formerly polluted sites. Knowledge about their performance and functions outside their natural distribution ranges can be of great importance, even under conditions of diminished air pollution. Also other environmental shifts, such as climate change, are likely to show how tree species are able to cope with new conditions (Kellomäki et al. 2018).

Specific needs, properties, and growth rates of tree species affect the utilization of nutrients available at a site in different ways even as their litterfall retroactively influences nutrient cycles (Perry et al. 1995). Although Norway spruce is reported to have negative impacts on soil properties, it is a natural component of the vegetation on most mountain sites of central Europe. It frequently has been reported that Norway spruce produces less-favourable forest floor properties compared with deciduous broadleaves (Binkley \& Valentine 1991, Augusto et al. 2002, Hagen-Thorn et al. 2004, Carnol \& Bazgir 2013). Many studies have been also published making comparisons among conifers. For instance, reported forest floor differences have included lower $\mathrm{pH}$ under Norway spruce, blue spruce and Serbian spruce (Picea omorika Purk.) compared to Scots pine (Pinus sylvestris L.) and white pine (Pinus strobus L.) on an air-polluted site in the Czech Republic (Kantor 1989); lower pH under Norway spruce compared to white pine in Connecticut, USA (Binkley \& Valentine 1991); higher $\mathrm{pH}$ under Douglas-fir (Pseudotsuga menziesii [Mirb.] Franco) compared to lodgepole pine (Pinus contorta Douglas - Thomas \& Prescott 2000); higher $\mathrm{pH}$ under white spruce (Picea glauca [Moench] Voss) compared to black spruce (Picea mariana Mill.) and red pine (Pinus resinosa Aiton) in Ontario, Canada (Mallik et al. 2008); comparable litter quality of black spruce and jack pine (Pinus banksiana Lamb.) in Canada (Preston et al. 2014); and no significant pH differences in western red cedar (Thuja plicata Donn ex D. Don), western hemlock (Tsuga heterophylla [Raf.] Sarg.), Douglas-fir, and Sitka spruce (Picea sitchensis [Bong.] Carrière) forest floors in Canada (Ribbons et al. 
2016). We took an approach in examining this matter different from those of earlier authors and focused upon the performance of Norway spruce and its effect on site properties in comparison with stands of six other Picea species.

The objective of our study was to compare the performance of a range of spruce species, the chemistry of their needles, and the properties of the forest floor (including topsoil) under young stands growing on a formerly air-polluted site in the Czech Republic. Excepting growth, no major difference between the introduced spruce species (white, black, red, Serbian, Sitka, and blue spruce) and the native Norway spruce were expected.

\section{Methods}

\section{Study site}

The evaluated forest stands are situated within the Jizerka research plot (see Balcar \& Podrázsky 1994) on the Czech side of the Jizera Mountains (Fig. 1). The research plot was established within a large clear-cut (more than 100 ha in size) created due to $\mathrm{SO}_{2}$ air pollution from Polish and German power plants. According to data from a nearby station (Slodičák et al. 2009), the air pollution peaked at mean annual $\mathrm{SO}_{2}$ concentration exceeding $40 \mu \mathrm{g} \mathrm{m}^{-3}$ in 1987 , a gradually and markedly decreasing load occurred thereafter, and the level was less than $5 \mu \mathrm{g} \mathrm{m}^{-3}$ in 2000. The experimental plantations are situated at an altitude of $970 \mathrm{~m}$ a.s.l., at a forest site of Piceetum acidophilum. Mean annual temperature of the research plot is $5.0^{\circ} \mathrm{C}$. During $1997-2010$, the coldest months were January and February $\left(-4.2\right.$ and $\left.-3.6^{\circ} \mathrm{C}\right)$ and the warmest ones were July and August $\left(14.4{ }^{\circ} \mathrm{C}\right)$. Mean annual precipitation was $1135 \mathrm{~mm}, 63 \%$ of which fell during the vegetation period (from May to October). The soil is a nutrient-poor, mountain podzol with raw forest floor humus (Nemeček et al. 2001). Deforested forest floor $(\mathrm{F}+\mathrm{H})$ showed a $\mathrm{pH}$ of 4.2-4.5 in water (Kacálek et al. 2013).

The experimental plantings consist of five North American spruce species and two of European origin. The treatments of white spruce ( $P$. glauca, Pg) from Sundown Creek and Eastville, Canada; black spruce ( $P$. mariana, Pm) from Petawawa, Canada; red spruce ( $P$. rubens, Pr) from Timber Lake, Canada; Sitka spruce ( $P$. sitchensis, Ps) from Cranberry River, Canada; blue spruce ( $P$. pungens, Pp) from Rio Grande, USA; Norway spruce (Picea abies, $\mathrm{Pa}$ ) from Deštné in the Orlice Mountains, Czech Republic; and Serbian spruce (P. omorika, Po) from Sarajevo, Federation of Bosnia and Hercegovina, were planted during 1990-1991 at $1 \times 2$ $\mathrm{m}$ spacing in pure square plots $10 \times 10 \mathrm{~m}$ in size. Three replicates were analysed for each spruce species in a design similar to a Latin square.

$\mathrm{Pm}$ gradually declined and was attacked by bark beetles in 2010. Since 2009, Pp has been infested by bud blight disease (Gemmamyces piceae - Černý et al. 2016), which causes its decline. Bud blight infestation of $\mathrm{Pg}$ also was found sporadically in the study plot.

\section{Stand performance analyses}

Each year (but with a two-year interval at the end of the experiment) the height (h, in $\mathrm{cm}$ ) of individual trees was measured within the experimental stands and the occurrence of stem deformation or other damage was evaluated in autumn. The height growth of individual tree species was assessed in this study until 2012, when these stands were thinned. Diameter at

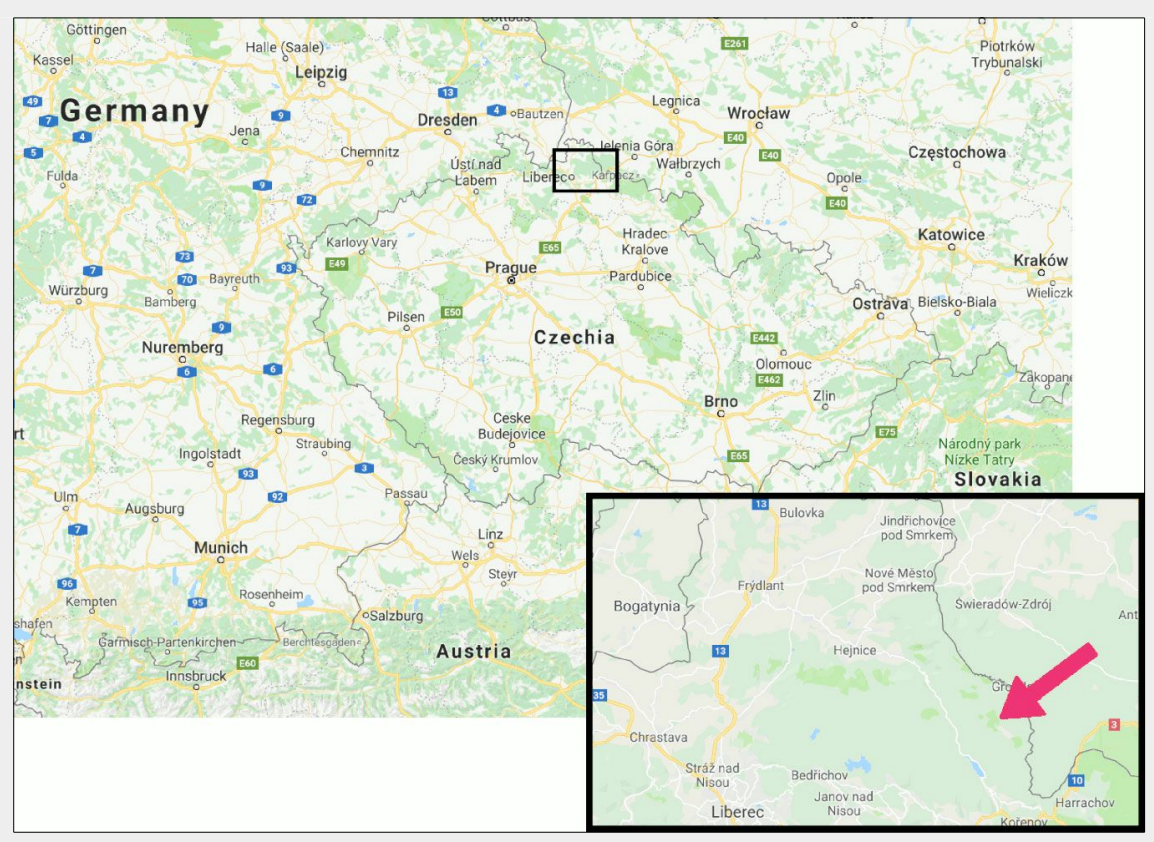

Fig. 1 - Location of the Jizerka research plot in the Jizera Mountains (source: Google Maps $\left.^{\top M}\right)$. breast height ( $\mathrm{DBH}$, in $\mathrm{cm}$ ) and $\mathrm{h} / \mathrm{DBH}$ (slenderness) ratio also were evaluated. The evaluation was made using data for $20 \%$ of the tallest trees from the actual number on each plot because they constitute the most dominant, vigorous trees.

\section{Foliar nutrient sampling and analysis}

In November 2011, samples of currentyear needles and one-year-old needles were taken for each spruce species. Needles were not sampled for black spruce due to decay of its stand in 2010. In five trees performing well on a plot, two branches were taken from the upper part of the crown. In the laboratory, a composite sample was produced for the individual needle age classes per parcel. For each spruce species, three composite samples were taken (i.e., three replications).

For each needle sample, the contents of basic nutrients ( $\mathrm{N}, \mathrm{P}, \mathrm{K}, \mathrm{Ca}, \mathrm{Mg}$, and $\mathrm{S}$ ) and of silicon were analysed using methods described by Zbíral (2001) and which are comparable with those of the ICP-Forests methodology (Rautio et al. 2016). The samples were mineralized, total nitrogen $(\mathrm{N})$ concentration was analysed by the Kjeldahl method, phosphorus $(P)$ was determined colorimetrically, potassium (K) was measured using an atomic absorption spectrophotometer, calcium ( $\mathrm{Ca}$ ) and magnesium $(\mathrm{Mg}$ ) were determined by atomic absorption after addition of lanthanum, and sulphur (S) and silicon (Si) were measured by the Balks method. The nutrient concentrations of Norway spruce were compared with foliar nutrition thresholds published by Mellert \& Göttlein (2012).

\section{Forest floor and topsoil analysis}

In autumn 2013, topsoil samples were taken using a sampling frame of internal size $25 \times 25 \mathrm{~cm}$ below the closed canopies of $\mathrm{Pa}, \mathrm{Pg}, \mathrm{Pr}$, and Ps stands, and in 2015 the topsoil was analysed also in $\mathrm{Pp}$ and $\mathrm{Po}$ stands. $\mathrm{L}+\mathrm{F}$ and $\mathrm{F}+\mathrm{H}$ horizons were separated and their total dry weight was determined. The A horizon also was separated. Each tree species was represented by three plots with three replications of samplings in each parcel (i.e., 9 replications per tree species).

Analysed parameters included oxidizable carbon $\left(\mathrm{C}_{\mathrm{ox}}\right)$, nitrogen according to Kjeldahl, acidity $\left(\mathrm{pH} / \mathrm{H}_{2} \mathrm{O}\right.$ and $\left.\mathrm{pH} / \mathrm{KCl}\right)$, sorption complex characteristics (base cation content - BCC, cation exchange capacity CEC, base saturation - BS) and nutrient contents by the Mehlich III method (Mehlich 1984).

\section{Data processing}

Based upon exploratory data analysis (EDA), data consistency was first assessed. Some nutrient ratios (N/P, N/K, N/Ca, K/Mg, $\mathrm{Ca} / \mathrm{Mg}$ ), describing nutrient balance were computed for macroelements in the needles. Using dry weight and nutrient ratios, nutrient pools in soil were computed for the $\mathrm{L}+\mathrm{F}$ and $\mathrm{F}+\mathrm{H}$ horizons. 
The data set from the analysis of particular needle age classes and soil horizons was evaluated by principal component analysis (PCA) using the FactoMineR package (Lê et al. 2008) in the R statistical software ( $R$ Core Team 2017). The evaluated parameters were the input variables and spruce species were the factors. The results of the analysis were visualized using the "ggbiplot" function (Vu 2011).

Using Student's t-test with Holm's adjustment (Holm 1979), the characteristics determined in individual introduced spruce species were compared statistically with the values determined in Norway spruce taken as a standard. The tests were run in the $\mathrm{R}$ statistical computing environment ver. 3.1.3 ( $R$ Core Team 2017) by means of the R Stats Package.

\section{Results}

\section{Stand development}

In the first ten years after planting, the mean height growth rate of the tallest $20 \%$ of Pa individuals was slower compared to those of the other spruces. In the following period up to 2012, however, its increment increased so as to catch up with the growth of the Ps, which was the tallest treatment after 20 years (height of $7.1 \mathrm{~m}$ in 2012 - Fig. 2). The height growth of Pm was comparable with that of Ps at the beginning, but the decay of its stand due to bark beetle occurred in 2010. Pp was the slowest-growing species and it was affected by bud blight. Pp stands also showed the highest average mortality rate $(41 \%)$ while the lowest mortality was in Ps (22\%). The differences between these mortality rates and that of Pa were not, however, statistically significant (Tab. 1). In the second half of the 1990s, necrotic damage to the needles of Po, Pm, and Pa was observed at the studied locality during winter. Current-year needles of $\mathrm{Pr}$ were also damaged at that time.

In 2012, both Pa and Ps were significantly taller than the other spruce species while Pa had significantly greater DBH compared to Pg, Pr, and Pp. The 2012 slenderness ratio was similar among the species, with the exception that Pp showed a significantly lower $\mathrm{h} / \mathrm{DBH}$ ratio compared to $\mathrm{Pa}$ (Tab. 1 ).

Deep snow cover in the 2004-2005 and 2005-2006 winter seasons (more than 200 $\mathrm{cm}$ at some places) caused trunk and top breaks of Pr and Pm trees (42\% and $40 \%$ of individuals, respectively) while the break frequency in $\mathrm{Pa}(24 \%)$ was close to the overall average.

\section{Foliar nutrient content}

In current-year needles, the first two axes of PCA explained $66.9 \%$ of data variance. The distribution of samples in multivariate space was indicated by differences in the chemistry of Pa needles, especially in comparison to $\mathrm{Pr}$ and $\mathrm{Po}$, and great data variance in Pg and Ps (Fig. 3a). In one-year-old needles, the two axes of PCA explained

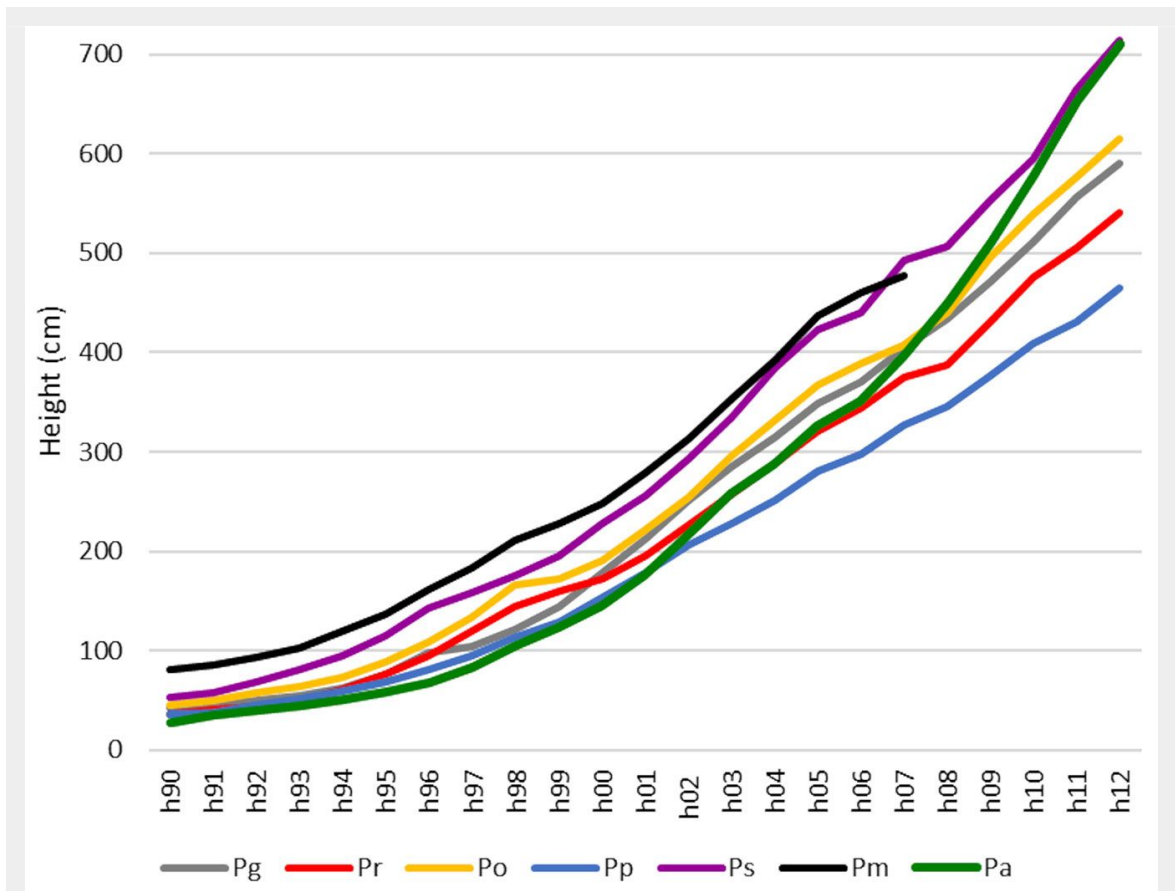

Fig. 2 - Mean height growth of the tree species within analysed stands (20\% of the tallest trees for each species) over the period 1990-2012. The years 2008-2009 were measured retrospectively. Relevant data are no longer available for $\mathrm{Pm}$ due to forest stand damage. (Pa): Picea abies; (Pg): P. glauca; (Pr): P. rubens; (Po): P. omorika; (Pp): $P$. pungens; (Ps): $P$. sitchensis; (Pm): P. mariana.

$65.6 \%$ of the total variance (Fig. 3b). The position of Pa points differs most markedly from those of the Pr and Pg points.

Statistical comparison of the parameters corresponded with the multivariate analysis. There was a trend for higher average content of $\mathrm{N}, \mathrm{P}$, and $\mathrm{Ca}$ in $\mathrm{Pa}$ needles compared to needles of the other spruces, but the differences were rarely significant. In the case of nitrogen, there was a significantly greater content in Pa compared to Po in current-year needles and to Pr in both needle age classes. Higher phosphorus in Pa needles was significant only in currentyear needles in comparison with Po and Ps. Calcium was also significantly higher in both needle age classes of Pa compared to $\mathrm{Pr}$ and in current-year needles in comparison with Ps (Tab. 2).

Potassium contents in individual spruce species were more differentiated, with significantly lower content found in currentyear needles of Pg and Pp compared to Pa. Magnesium was significantly lower only in one-year-old needles of Pp.

Sulphur contents in needles of all introduced species were similar to the values in $\mathrm{Pa}$. The largest differences were measured in silicon content, which was significantly lower in the non-native spruce species compared to $\mathrm{Pa}$ in both needle age classes (except the current-year needles in the case of Pg - Tab. 2).

The N/P ratio in Pa was among the lowest, but with the exception of current-year needles of Ps these differences were not significant (Tab. 3). In current-year needles, the $\mathrm{N} / \mathrm{K}$ ratio in $\mathrm{Pa}$ was significantly higher

Tab. 1 - Cumulative mortality during 1990-2012, as well as height (h), DBH, and slenderness ratios ( $\mathrm{h} / \mathrm{d}$ ) of individual tree species in 2012. Asterisks indicate significant differ ences between Norway spruce (first row) and the respective non-native spruce species (t-test with Holm's adjustment). $\left({ }^{*}\right)$ : $p<0.05$; (**): $p<0.01$; (SD): standard deviation; (Pa): Picea abies; (Pg): P. glauca; (Pr): P. rubens; (Po): P. omorika; (Pp): P. pungens; (Ps): P. sitchensis; (Pm): P. mariana.

\begin{tabular}{ccrlccccr}
\hline \multirow{2}{*}{ Species } & \multicolumn{2}{c}{ Mortality $(\%)$} & \multicolumn{2}{c}{ h $(\mathbf{c m})$} & \multicolumn{2}{c}{ DBH $(\mathbf{c m})$} & \multicolumn{2}{c}{ h/d } \\
\cline { 2 - 9 } & mean & SD & mean & SD & mean & SD & mean & \multicolumn{1}{c}{ SD } \\
\hline $\mathrm{Pa}$ & 27.5 & 13.5 & 709.5 & 64.2 & 12.9 & 2.6 & 56.7 & 10.3 \\
\hline $\mathrm{Pg}$ & 25.5 & 9.0 & $590.4^{* *}$ & 48.3 & $10.4^{* *}$ & 1.7 & 57.9 & 7.0 \\
$\mathrm{Pr}$ & 29.3 & 15.4 & $541.4^{* *}$ & 46.4 & $9^{* *}$ & 2.0 & 57.2 & 11.7 \\
$\mathrm{Po}$ & 29.0 & 3.0 & $615.0^{* *}$ & 36.0 & 11.4 & 2.1 & 55.7 & 9.5 \\
$\mathrm{Pp}$ & 41.0 & 12.0 & $465.4^{* *}$ & 52.4 & $10.4^{* *}$ & 1.6 & $45.2^{* *}$ & 5.4 \\
$\mathrm{Ps}$ & 22.0 & 2.0 & 714.1 & 66.5 & 11.9 & 2.2 & 61.6 & 9.8 \\
\hline
\end{tabular}



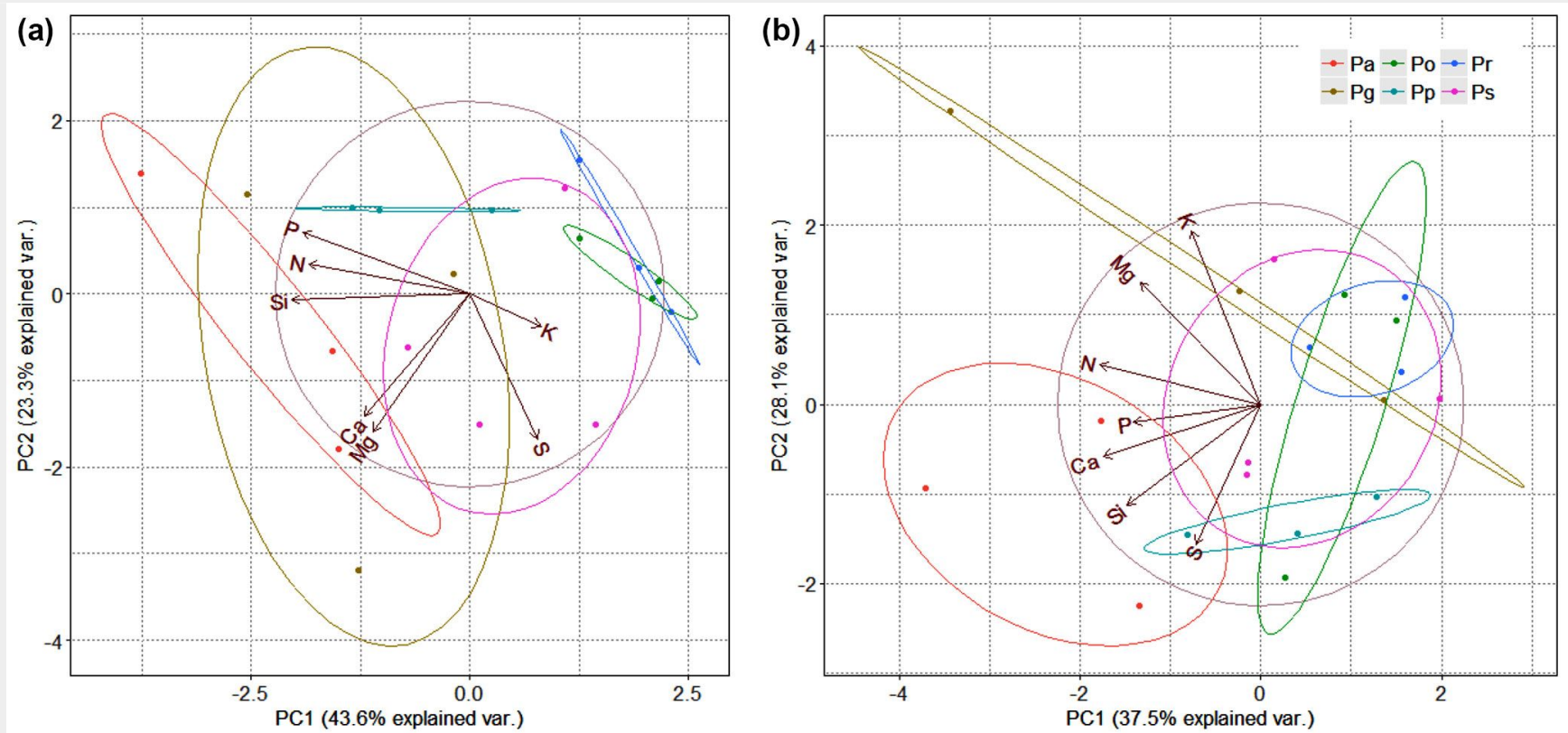

Fig. 3 - Ordination diagram from principal component analysis of macroelement contents in current-year (a) and one-year-old (b) needles. Percentage expresses variance explained by the two axes. (Pa): Picea abies; (Pg): P. glauca; (Pr): P. rubens; (Po): P. omorika; (Pp): P. pungens; (Ps): P. sitchensis; (Pm): P. mariana.

Tab. 2 - Percentage content of macroelements and silicon (mean and standard deviation, SD) in current-year (cy) and one-year-old (oy) needles of tested spruce species. Asterisks indicate significant differences in nutrient contents within needle age classes between Norway spruce and the respective non-native spruce species ( $t$-test with Holm's adjustment): $(*): p<0.05 ;(* *): p<0.01$. (Pa): Picea abies; (Pg): P. glauca; (Pr): P. rubens; (Po): P. omorika; (Pp): P. pungens; (Ps): P. sitchensis; (Pm): P. mariana.

\begin{tabular}{|c|c|c|c|c|c|c|c|c|c|c|c|c|c|c|c|}
\hline \multirow{2}{*}{ Species } & \multirow{2}{*}{$\begin{array}{c}\text { Needle } \\
\text { age } \\
\text { class }\end{array}$} & \multicolumn{2}{|c|}{$\mathrm{N}$} & \multicolumn{2}{|c|}{$\mathbf{P}$} & \multicolumn{2}{|c|}{$K$} & \multicolumn{2}{|c|}{$\mathrm{Ca}$} & \multicolumn{2}{|c|}{$\mathrm{Mg}$} & \multicolumn{2}{|c|}{ S } & \multicolumn{2}{|c|}{$\mathrm{Si}$} \\
\hline & & mean & SD & mean & SD & mean & SD & nean & SD & mean & SD & mean & SD & mean & SD \\
\hline \multirow{2}{*}{$\mathrm{Pa}$} & cy & 1.38 & 0.10 & 0.086 & 0.010 & 0.54 & 0.02 & 0.47 & 0.00 & 0.106 & 0.011 & 0.157 & 0.023 & 0.27 & 0.03 \\
\hline & oy & 1.45 & 0.22 & .082 & 0.015 & 0.55 & 0.09 & 0.77 & 0.04 & 0.097 & 0.009 & 0.169 & .015 & .49 & 0.03 \\
\hline \multirow{2}{*}{$\mathrm{Pg}$} & cy & 1.28 & 0.1 & 070 & 0. & * & 0.0 & 4 & 0 & 06 & 0 & 1 & .017 & 9 & 0.02 \\
\hline & oy & 1.32 & 0.29 & 061 & 0.008 & 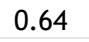 & 0. & 0.60 & 0.1 & 38 & 0.052 & 0.139 & 0.003 & $1^{* *}$ & 0.03 \\
\hline \multirow{2}{*}{$\mathrm{Pr}$} & cy & $1.05^{*}$ & 0.07 & 0.063 & 0.001 & 0.5 & 0. & 0.2 & 0.0 & 0.084 & 0.002 & 0.160 & 0.013 & $2^{* *}$ & 0.01 \\
\hline & oy & $1.08^{*}$ & 0.08 & 0.062 & 0.010 & 0.60 & 0.07 & $0.42^{*}$ & 0.04 & 0.091 & 0.013 & 0.150 & 0.015 & $.16^{* *}$ & 0.03 \\
\hline \multirow{2}{*}{ Po } & cy & $1.08^{*}$ & 0.05 & $0.058^{*}$ & 0.003 & 0.59 & 0.06 & 0.36 & 0.05 & 0.089 & 0.006 & 0.151 & 0.006 & $0.08^{*}$ & 0.05 \\
\hline & oy & 1.26 & 0.11 & 0.058 & 0.006 & 0.52 & 0.10 & 0.47 & 0.19 & 0.087 & 0.009 & 0.163 & 0.012 & $0.13^{* *}$ & 0.08 \\
\hline \multirow{2}{*}{$p$} & cy & 1.24 & 0.06 & 0.079 & 0.004 & $0.46^{*}$ & 0.02 & 0.37 & 0.04 & 0.094 & 0.007 & 0.142 & 0.011 & $0.18^{*}$ & 0.03 \\
\hline & oy & $1.21^{*}$ & 0.02 & 0.071 & 0.011 & 0.42 & 0.03 & 0.56 & 0.19 & $0.069^{*}$ & 0.010 & 0.157 & 0.003 & $0.34^{* *}$ & 0.03 \\
\hline \multirow[b]{2}{*}{ PS } & cy & 1.22 & 0.11 & $0.059^{*}$ & 0.009 & 0.64 & 0.12 & $0.38^{*}$ & 0.03 & 0.107 & 0.015 & 0.155 & 0.016 & $0.16^{*}$ & 0.03 \\
\hline & oy & 1.20 & 0.09 & 0.052 & 0.018 & 0.54 & 0.09 & 0.67 & 0.09 & 0.090 & 0.007 & 0.149 & 0.017 & $0.23^{* *}$ & 0.03 \\
\hline
\end{tabular}

Tab. 3 - Nutrient ratios (mean and standard deviation, SD) in current-year (cy) and one-year-old (oy) needles of tested spruce species. Asterisks indicate significant differences in nutrient ratios within needle age classes between Norway spruce and the respective non-native spruce species (t-test with Holm's adjustment): $\left(^{*}\right): p<0.05 ;\left({ }^{* *}\right): p<0.01 .(P a)$ : Picea abies; (Pg): P. glauca; (Pr): P. rubens; (Po): P. omorika; (Pp): P. pungens; (Ps): P. sitchensis; (Pm): P. mariana.

\begin{tabular}{|c|c|c|c|c|c|c|c|c|c|c|c|}
\hline \multirow{2}{*}{ Species } & \multirow{2}{*}{$\begin{array}{l}\text { Needle } \\
\text { age class }\end{array}$} & \multicolumn{2}{|c|}{ N/P } & \multicolumn{2}{|c|}{$\mathrm{N} / \mathrm{K}$} & \multicolumn{2}{|c|}{$\mathrm{N} / \mathrm{Ca}$} & \multicolumn{2}{|c|}{$\mathrm{K} / \mathrm{Mg}$} & \multicolumn{2}{|c|}{$\mathrm{Ca} / \mathrm{Mg}$} \\
\hline & & mean & SD & mean & SD & mean & SD & mean & SD & mean & SD \\
\hline \multirow{2}{*}{$\mathrm{Pa}$} & cy & 16.1 & 0.7 & 2.6 & 0.2 & 2.9 & 0.2 & 5.1 & 0.7 & 4.5 & 0.5 \\
\hline & oy & 18.0 & 2.5 & 2.7 & 0.4 & 1.9 & 0.2 & 5.7 & 1.4 & 7.9 & 0.7 \\
\hline \multirow{2}{*}{$\mathrm{Pg}$} & cy & 18.4 & 1.2 & 3.3 & 0.5 & 2.7 & 1.1 & 3.8 & 0.3 & 5.2 & 1.3 \\
\hline & oy & 21.6 & 4.1 & 2.1 & 0.3 & 2.2 & 0.2 & 4.9 & 1.0 & $4.5^{* *}$ & 0.3 \\
\hline \multirow{2}{*}{$\mathrm{Pr}$} & cy & 16.6 & 1.0 & $1.8^{*}$ & 0.3 & 3.8 & 0.5 & $7.1^{*}$ & 0.4 & $3.3^{*}$ & 0.1 \\
\hline & oy & 17.8 & 2.7 & 1.8 & 0.3 & 2.6 & 0.4 & 6.8 & 1.8 & $4.8^{*}$ & 1.2 \\
\hline \multirow{2}{*}{ Po } & cy & 18.8 & 1.7 & $1.8^{* *}$ & 0.2 & 3.1 & 0.6 & $6.6^{*}$ & 0.3 & 4.0 & 0.6 \\
\hline & oy & 22.2 & 4.0 & 2.5 & 0.4 & 3.1 & 1.2 & 6.0 & 0.8 & 5.6 & 2.6 \\
\hline \multirow{2}{*}{$\mathrm{Pp}$} & cy & 15.7 & 1.0 & 2.7 & 0.2 & 3.3 & 0.4 & 4.9 & 0.5 & 4.0 & 0.1 \\
\hline & oy & 17.5 & 2.8 & 2.9 & 0.2 & 2.6 & 1.2 & 6.2 & 0.9 & 7.9 & 2.3 \\
\hline \multirow{2}{*}{ Ps } & cy & $21.1^{*}$ & 2.7 & 1.9 & 0.3 & 3.2 & 0.4 & 6.0 & 0.7 & $3.6^{*}$ & 0.3 \\
\hline & oy & 26.5 & 9.9 & 2.3 & 0.4 & 1.8 & 0.2 & 6.0 & 0.7 & 7.5 & 0.8 \\
\hline
\end{tabular}


than were those for Pr and Po. The N/Ca ratio was highly variable and no statistical differences were found. The $\mathrm{K} / \mathrm{Mg}$ ratio was lowest in Pg, followed by Pa; compared to $\mathrm{Pa}$ it was significantly higher in currentyear needles of $\mathrm{Pr}$ and $\mathrm{Po}$. The $\mathrm{Ca} / \mathrm{Mg}$ ratio in $\mathrm{Pa}$ needles was significantly higher in current-year needles compared to $\mathrm{Pr}$ and $P s$ and in one-year-old needles in comparison with $\mathrm{Pr}$ and $\mathrm{Pg}$ (highly significant - Tab. 3).

\section{Forest floor and soil}

Dry matter of the $\mathrm{L}+\mathrm{F}$ horizon in individual spruce species accounted on average for $8.5 \%$ (in Po) to $30.3 \%$ (in Ps) of the total dry matter of forest floor $(\mathrm{L}+\mathrm{F}+\mathrm{H})$. Mean total dry weight of forest floor layers in stands of the analysed species ranged from 12.4 to $14.3 \mathrm{~kg} \mathrm{~m}^{-2}$, without significant differences between $\mathrm{Pa}$ and the other spruce species. The greatest variation in values was observed under $\mathrm{Pa}$ (Tab. 4).

The PCA multivariate comparison of particular horizons data provided no interpretable outputs in spite of the relatively high probability of data variance explained (the first two axes explained $60.1-65.7 \%$ of the variance).

The soil $\mathrm{pH}$ values for all horizons were very strongly acid (according to Sáňka \& Materna 2004). No differences in $\mathrm{pH} / \mathrm{H}_{2} \mathrm{O}$ values were found between soil horizons under $\mathrm{Pa}$ and the other species. The $\mathrm{pH} / \mathrm{KCl}$ value in $\mathrm{Pa}$ was significantly lower in the $\mathrm{F}+\mathrm{H}$ horizon compared to that of the Po and $\mathrm{Pp}$ stands (Tab. S1 in Supplementary material).

Among the sorption complex characteristics, a significantly higher value of CEC-BCC difference was revealed in the $\mathrm{L}+\mathrm{F}$ horizon in $\mathrm{Pa}$ compared to $\mathrm{Pg}, \mathrm{Po}$, and $\mathrm{Pp}$; in the $\mathrm{F}+\mathrm{H}$ horizon, it was also higher than in Ps. In the soil under $\mathrm{Pa}$ within the L+F horizon, the CEC value was significantly higher than for $\mathrm{Po}$ and in $\mathrm{F}+\mathrm{H}$ higher than for $\mathrm{Pg}$ and Ps.

With the exception of significantly higher $\mathrm{P}$ content in the A horizon under Pp, no

Tab. 4 - Dry weight (mean and standard deviation, SD) of forest floor horizons $(L+F$, $\mathrm{F}+\mathrm{H}$, and in total). Differences between $\mathrm{Pa}$ and other spruce species were not significant. (Pa): Picea abies; (Pg): P. glauca; (Pr): P. rubens; (Po): P. omorika; (Pp): P. pungens; (Ps): P. sitchensis; (Pm): P. mariana.

\begin{tabular}{|c|c|c|c|c|c|c|c|c|c|c|c|c|}
\hline \multirow{2}{*}{$\begin{array}{l}\text { Hori- } \\
\text { zon }\end{array}$} & \multicolumn{2}{|c|}{$\mathrm{Pa}\left(\mathrm{kg} \mathrm{m}^{-2}\right)$} & \multicolumn{2}{|c|}{$\mathrm{Pg}\left(\mathrm{kg} \mathrm{m}^{-2}\right)$} & \multicolumn{2}{|c|}{$\operatorname{Pr}\left(\mathrm{kg} \mathrm{m}^{-2}\right)$} & \multicolumn{2}{|c|}{ Po $\left(\mathrm{kg} \mathrm{m}^{-2}\right)$} & \multicolumn{2}{|c|}{$\mathrm{Pp}\left(\mathrm{kg} \mathrm{m}^{-2}\right)$} & \multicolumn{2}{|c|}{ Ps $\left(\mathrm{kg} \mathrm{m}^{-2}\right)$} \\
\hline & mean & SD & mean & SD & mean & SD & mean & SD & mean & SD & mean & SD \\
\hline & & .4J & & 1.3 & & 1.57 & & 0.45 & & 1. & & 0. \\
\hline & & .18 & 9.40 & 3.89 & 8.72 & 5.13 & 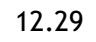 & 2.84 & & 3.17 & 8 & 3.51 \\
\hline otal & 4.26 & 4.50 & 12.70 & 2.97 & 12.35 & 3.76 & 13.43 & 2.58 & 12.91 & 4.00 & 13.89 & 3.20 \\
\hline
\end{tabular}

other significant differences in element contents in soil horizons were found between $\mathrm{Pa}$ and the introduced spruce species (Tab. S1 in Supplementary material).

\section{Nutrient pools}

Even though there was great variability in the forest floor nutrient pools ( $\mathrm{kg} \mathrm{ha}^{-1}$ ) under stands of individual spruce species, few statistically significant differences were apparent (Tab. 5). Although the average pool of $\mathrm{C}_{\mathrm{ox}}$ in the $\mathrm{L}+\mathrm{F}$ layer differed between $\mathrm{Pa}$ and $\mathrm{Po}$ and between $\mathrm{Pa}$ and Pp, these differences were not statistically significant. Only a smaller pool of $\mathrm{P}$ and $\mathrm{K}$ under Po compared to Pa was confirmed. The pools of elements in the $\mathrm{F}+\mathrm{H}$ layer, similarly to the sums of the pools of both forest floor horizons $(\mathrm{L}+\mathrm{F}+\mathrm{H})$, did not show any significant differences.

\section{Discussion}

\section{Spruce species growth and health}

Norway spruce was the slowest growing among all the spruce species tested during 1990-2001. Its growth rate then accelerated and the height was found to be comparable with that of Sitka spruce, which performed well from the very beginning. The improvement in the growth parameters of Norway spruce reflected the diminishing stress from air pollution (Slodičák et al. 2009, Oulehle et al. 2011, Lomský et al. 2012, Novotny et al. 2017). Novotny et al. (2013) had found a relationship between decreasing defoliation and increasing height increment among Norway spruce in the Ore Mountains during a period (19952010) closely corresponding to that of our study (1990-2012) in the Jizera Mountains.

Winter necrotic injury of needles observed in most spruce species was associated with periods of extremely low temperature, and this has been reported also in other regions. For example, winter injury of red spruce needles is well known from its natural distribution range (Lazarus et al. 2006). Because the occurrence of this spruce species in Central European forests is negligible, we need not be worried about its susceptibility to freezing necrosis of needles.

A massive decline of black spruce was recorded due to an attack in summer 2010 by bark beetles, in particular by pine bark beetle (Pityogenes chalcographus) and the smaller eight-toothed spruce bark beetle (Ips amitinus). Both bark beetles were reported as dangerous for young stands of Norway spruce on the Polish side of the Jizera Mountains (Grodzki 2009). Black spruce normally grows on waterlogged sites (Preston et al. 2014), but the study plot is not such a site. Hence, it is assumed that the black spruce trees were weakened by environmental conditions different from those of its natural range.

\section{Foliar nutrient content}

Nutrient contents in Norway spruce needles indicated a sufficient nitrogen reserve

Tab. 5 - Nutrient pools (mean and standard deviation, SD) in $\mathrm{L}+\mathrm{F}$ and $\mathrm{F}+\mathrm{H}$ horizons. Asterisks indicate significant differences between Pa and particular non-native spruce species (t-tests with Holm's adjustment). $(*): p<0.05 ;(* *): p<0.01$. (Pa): Picea abies; (Pg): P. glauca; (Pr): P. rubens; (Po): P. omorika; (Pp): P. pungens; (Ps): P. sitchensis; (Pm): P. mariana.

\begin{tabular}{|c|c|c|c|c|c|c|c|c|c|c|c|c|c|}
\hline \multirow{2}{*}{ Horizons } & \multirow{2}{*}{ Stand } & \multicolumn{2}{|c|}{ 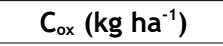 } & \multicolumn{2}{|c|}{$N\left(k_{g} a^{-1}\right)$} & \multicolumn{2}{|c|}{$P\left(\mathrm{~kg} \mathrm{ha}^{-1}\right)$} & \multicolumn{2}{|c|}{$K\left(\mathrm{~kg} \mathrm{ha}^{-1}\right)$} & \multicolumn{2}{|c|}{$\mathrm{Ca}\left(\mathrm{kg} \mathrm{ha}^{-1}\right)$} & \multicolumn{2}{|c|}{$M g\left(\mathrm{~kg} \mathrm{ha}^{-1}\right)$} \\
\hline & & mean & SD & mean & SD & mean & SD & mean & SD & mean & SD & mean & SD \\
\hline \multirow{6}{*}{$L+F$} & $\mathrm{~Pa}$ & 1269.2 & 507.4 & 53.3 & 18.1 & 0.21 & 0.04 & 2.81 & 0.72 & 6.61 & 2.24 & 1.54 & 0.73 \\
\hline & $\mathrm{Pg}$ & 1227.6 & 482.7 & 50.6 & 22.3 & 0.17 & 0.06 & 1.83 & 0.61 & 6.08 & 2.36 & 1.68 & 1.35 \\
\hline & $\operatorname{Pr}$ & 1343.3 & 571.2 & 55.3 & 24.5 & 0.18 & 0.08 & 2.15 & 1.28 & 6.52 & 3.17 & 1.79 & 1.17 \\
\hline & Po & 519.7 & 197.2 & 21.2 & 8.7 & $0.08^{*}$ & 0.04 & $0.74^{*}$ & 0.28 & 3.19 & 2.01 & 0.48 & 0.14 \\
\hline & $\mathrm{Pp}$ & 860.3 & 716.4 & 45.8 & 51.2 & 0.15 & 0.15 & 1.87 & 1.56 & 6.38 & 5.43 & 1.39 & 1.26 \\
\hline & Ps & 1781.4 & 518.5 & 63.4 & 11.7 & 0.22 & 0.05 & 3.00 & 1.31 & 9.41 & 1.96 & 2.34 & 0.37 \\
\hline \multirow{6}{*}{$\mathrm{F}+\mathrm{H}$} & $\mathrm{Pa}$ & 3603.4 & 2022.8 & 149.1 & 89.3 & 0.41 & 0.25 & 4.27 & 2.15 & 17.37 & 10.46 & 5.55 & 4.57 \\
\hline & $\mathrm{Pg}$ & 2914.5 & 1363.4 & 132.8 & 66.2 & 0.32 & 0.21 & 3.10 & 1.70 & 12.25 & 6.26 & 3.48 & 1.38 \\
\hline & $\operatorname{Pr}$ & 2683.9 & 1943.6 & 120.7 & 84.0 & 0.25 & 0.19 & 2.65 & 1.72 & 14.47 & 10.19 & 4.63 & 3.64 \\
\hline & Po & 3878.9 & 977.5 & 182.5 & 34.0 & 0.36 & 0.18 & 4.30 & 0.88 & 20.31 & 5.34 & 6.42 & 2.08 \\
\hline & $\mathrm{Pp}$ & 3198.1 & 928.5 & 165.7 & 39.1 & 0.47 & 0.26 & 4.02 & 1.58 & 18.25 & 4.55 & 5.63 & 2.07 \\
\hline & Ps & 2120.4 & 976.2 & 86.4 & 44.8 & 0.17 & 0.04 & 2.13 & 0.74 & 11.85 & 5.08 & 3.58 & 2.21 \\
\hline
\end{tabular}


(Mellert et al. 2004, Srámek et al. 2009). More specifically, it was at the boundary between the lower normal level (1.40-1.50\% $\mathrm{N})$ and latent deficiency $(1.18-1.40 \% \mathrm{~N}$ Mellert \& Göttlein 2012). The level of phosphorus was identified at the threshold of extreme deficiency below $0.09 \%$ of dry matter. The potassium level was at the low end of normal, between 0.52 and $0.61 \%$. Calcium ranged from intermediate normal to the abundant level (0.44-0.81\%), and magnesium was at the intermediate normal level (between 0.09 and $0.12 \%$ of dry matter - Mellert \& Göttlein 2012). No substantial differences in foliar nutrient contents were revealed between individual spruce species. Nevertheless, finding similar foliar contents among conifers at the same site is not surprising, given that Alexander (2014) documented non-significant differences in $\mathrm{Mg}$ foliar content in needles of ponderosa pine (Pinus ponderosa), Douglas-fir (Pseudotsuga menziesii), and incense cedar (Calocedrus decurrens [Torr.] Florin), even though soil $\mathrm{Mg}$ had been significantly influenced by serpentine bedrock compared to the soil on gabbro bedrock. Neither did Kranabetter \& Coates (2004) find any differences in $\mathrm{N}$ content in the needles of a white spruce $\times$ Sitka spruce hybrid, of western red cedar (Thuja plicata), and of western hemlock (Tsuga heterophylla) growing in conditions of previously clear-cut, partial-cut, and unharvested forest. Kranabetter \& Banner (2000) reported no significant differences in hemlock needles among stands on four different bedrocks (granodiorite, gneiss diorite, amphibolite, and limestone), though such soil properties as $\mathrm{pH} / \mathrm{H}_{2} \mathrm{O}, \mathrm{P}$, and $\mathrm{Mg}$ and forest floor properties as $\mathrm{pH} / \mathrm{H}_{2} \mathrm{O}, \mathrm{N}, \mathrm{P}, \mathrm{S}$, and $\mathrm{C} / \mathrm{N}$ showed significant differences. In air-polluted conditions, such soil-improving measures as additions of fertilizing rocks have been found promising (Nárovec \& Šach 1994) and also have been tested many times. Blonska et al. (2015) found the addition to soil of dolomite (2-4 Mg ha-1), magnesite (2-4 Mg ha-1), and serpentine (2$4 \mathrm{Mg} \mathrm{ha}^{-1}$ ) did not improve the foliar nutrient status of Norway spruce compared to a no-fertilizer control. As measured by nutrient concentrations in Norway spruce needles, application of dolomitic limestone within the Jizerka study site (see methods and Balcar \& Podrázsky 1994) was not observed to have any explicit effect. Limed sample trees at the Jizerka site did, however, produce more dry matter, and consequently they had larger pools of N, P, K, Ca, $\mathrm{Mg}$, and $\mathrm{S}$ than did a control (Kuneš et al. 2007). Therefore, even minor differences in nutrient concentrations in the plant material of individual spruces in our study may be manifested as significant due to differences in total biomass. Thus, biomass nutrient pools are likely to be driven also by parameters such as height, as documented by Power et al. (2014) for black spruce and white spruce in examining the relationship between total tree foliage biomass and
$\mathrm{DBH}$, total height, and crown length.

Matsushima et al. (2012) documented an increase in foliar $\mathrm{N}$ in white spruce needles after removing competitive ground vegetation and fertilizing with nitrogen, which increased the availability of this nutrient. Silvicultural measures such as weed control and $\mathrm{N}$-fertilization can help to improve foliar status of spruce stands in the boreal conditions characteristic of the study site. Mason (2014) reported moderate differences in foliar contents of $\mathrm{N}, \mathrm{P}$, and $\mathrm{K}$ in Sitka spruce needles when grown in pure stands versus when admixed with Japanese larch (Larix kaempferi [Lam.] Carrière) and tamarack (Larix laricina [Du Roi] K. Koch). In needles of 25-year-old Sitka spruce, Mason (2014) revealed a moderate increase in $\mathrm{N}$ and $\mathrm{K}$ and at the same time a moderate decrease in $\mathrm{P}$ in treatments mixed with both larches, but statistical significance of these differences was not mentioned. For Sitka spruce in the Jizera Mountains, foliar N content (1.22\%) corresponded with that of 15 -year-old Sitka (1.23\%) in the north-east of Scotland (Mason 2014), but $P$ (0.06\%) and $\mathrm{K}(0.64 \%)$ contents were excessively low compared to the $0.3 \% \mathrm{P}$ and 1.34\% K reported by Mason (2014). Our results indicated very low phosphorus concentrations ranging from 0.06 to $0.09 \%$ in current-year needles and from 0.05 to $0.08 \%$ in one-year-old needles in all sampled spruce species (Tab. 2), likely reflecting insufficient nutrition (Srámek et al. 2009). This also affected substantially the values of N/P (Tab. 3), as optimal N/P should range from 7.01 to 10.00 according to Srámek et al. (2009). A previous study from the same study site (Kacálek et al. 2013) also had documented very low foliar phosphorus $(0.07 \%)$ in Norway spruce needles. The deficiency of available phosphorus in the soil layer of $0-30 \mathrm{~cm}$ was previously documented in this part of the eastern Jizera Mountains where the study plot is situated (Boruvka in Slodičák et al. 2009). It is apparent that neither the supply of available nutrients nor efficient intake by the plant strictly determine tree performance. For example, Nitschke et al. (2017) stated that white spruce, as a more efficient nutrient user, is capable of thriving on sites with limited nutrient availability on sites in south-eastern Yukon, Canada. Castle \& Neff (2009) concluded that foliar concentrations are not good indicators of nutrient availability in topsoil. Prescott et al. (2000) reported a very weak relationship between nutrient contents in assimilation organs and in forest floor, and this corresponds also with our findings.

\section{Forest floor and soil}

A part of the forest floor whose properties can be directly influenced by tree species is the upper, least decomposed layer of litter and detritus ( $L+F)$. In our study, the smallest amount of $L+F$ material was found under Serbian spruce. At deeper layers $(\mathrm{F}+\mathrm{H})$, however, no differences in the amount of forest floor were observed between the non-native spruces and Norway spruce. The accumulation of this material through litterfall substantially influences the total pool of nutrients in forest floor (Mallik et al. 2008). For the six spruces, the calculation of nutrient reserve in humus horizons based on their dry matter revealed no statistically significant differences between Norway spruce and the other spruce species, thus indicating their comparable roles in accumulating nutrients in soil.

Aitkenhead-Peterson et al. (2006) found a strong negative correlation between foliar $\mathrm{N}$ and the $\mathrm{C} / \mathrm{N}$ ratio of forest floor. Our study pointed to a negligible negative correlation between foliar $\mathrm{N}$ and $\mathrm{C} / \mathrm{N}$ in the upper layer of forest floor $(L+F)$. For currentyear needles, the $R^{2}$ was 0.051 and the $R^{2}$ for needles one year old was 0.022 . The correlation between foliar $\mathrm{N}$ and $\mathrm{C} / \mathrm{N}$ in the $\mathrm{F}+\mathrm{H}$ layer was already positive (currentyear needles $R^{2}=0.138$, one-year-old needles $\left.R^{2}=0.144\right)$. A strong negative correlation $\left(R^{2}=0.844\right)$ was confirmed between nitrogen continent in the $\mathrm{L}+\mathrm{F}$ layer and the $\mathrm{C} / \mathrm{N}$ ratio of the same layer. Although the properties of forest floor can differ in relation to the parent rock, they are far from reflecting its composition (Kranabetter \& Banner 2000). Strong roles are played also by climate and vegetation. Prescott et al. (2000) reported only a weak correlation between the element contents in living needles and those in forest floor material, with the only significant relationships observed being those for $\mathrm{Ca}$ and $\mathrm{K}$. In our study, there was a significant (but still quite weak) correlation only between foliar $P$ and $P$ content in $L+F$ forest floor $\left(R^{2}=\right.$ 0.434). A previous study from the same site had shown conifers such as Norway spruce, mountain pine (Pinus mugo Turra), and European larch (Larix decidua Mill.) to be capable of contributing to the higher phosphorus contents of the forest floor compared to those in broadleaved forest and in grass-dominated patches (Kacálek et al. 2013).

\section{Conclusions}

The comparison of performance, foliar nutrient content, and forest floor under 20 year-old spruce stands on the formerly airpolluted mountain site revealed only minor differences between native Norway spruce $(\mathrm{Pa})$ and the introduced spruces. As regards height growth, in spite of initial differences, the performance of $\mathrm{Pa}$ was improving over time relative to those of $\mathrm{Pp}$, $\mathrm{Pr}, \mathrm{Pg}$, and $\mathrm{Po}$, while Ps performed well throughout the entire period of interest. Pm (due to bark beetle attack) and Pp (due to growth rate and bud blight decline) performed the worst of all. The differences in foliar nutrient concentrations between $\mathrm{Pa}$ and other spruce species were negligible, although mostly lower concentrations in the introduced spruces were indicated. Chemistry of the upper soil horizons under 
Pa and other spruces was similar. There were no significant differences in the forest floor nutrient pools, thus indicating the comparable impact of $\mathrm{Pa}$ and other spruces on the site. There has been an obvious recovery in the growth of native $\mathrm{Pa}$ compared to the non-native spruces with the exception of Ps. This indicates that it is no longer necessary to plant non-native tree species as replacements for Norway spruce. Further research could determine whether Sitka spruce, which is native to an oceanic climate, can perform comparably with Norway spruce on a montane site in central Europe's improved pollution conditions.

\section{Acknowledgements}

This study was supported by the Ministry of Agriculture of the Czech Republic within MZE-RO0118 institutional support and research project QJ1520291. The authors would like to thank three anonymous reviewers for valuable comments on an earlier version of the manuscript and also Gale A. Kirking (English Editorial Services) for editing the language.

\section{References}

Aitkenhead-Peterson JA, Alexander JE, Albrechtova J, Krám P, Rock B, Cudlín P, Hruška J, Lhotaková Z, Huntley R, Oulehle F, Polák T, McDowell WH (2006). Linking foliar chemistry to forest floor solid and solution phase organic $C$ and $\mathrm{N}$ in Picea abies [L.] Karst. stands in northern Bohemia. Plant and Soil 283: 187-201. - doi: 10.1007/s11104-006-0010-7

Alexander EB (2014). Foliar analyses of conifers on serpentine and gabbro soils in the Klammath mountains. Madroño 61 (1): 77-81. [online] URL: http://www.jstor.org/stable/432886 69

Augusto L, Ranger J, Binkley D, Rothe A (2002). Impact of several common tree species of European temperate forests on soil fertility. Annals of Forest Science 59: 233-253. - doi: 10.105 1/forest:2002020

Balcar V (1996). Acute air pollution injury of ten coniferous species in the Trutnov region. Lesnictví-Forestry 42 (10): 460-472.

Balcar V, Podrázsky V (1994). Založení výsadbového pokusu $v$ hrebenové partii Jizerských hor [Establishment of a tree planting experiment in the ridge part of the Jizerské hory Mts]. Reports of Forestry Research - Zprávy lesnického výzkumu 39 (2): 1-7. [in Czech]

Binkley D, Valentine D (1991). Fifty-year biogeochemical effects of green ash, white pine, and Norway spruce in a replicated experiment. Forest Ecology and Management 40: 13-25. - doi: 10.1016/0378-1127(91)90088-D

Blonska E, Malek S, Januszek K, Barszcz J, Wanic $T$ (2015). Changes in forest soil properties and spruce stands characteristics after dolomite, magnesite and serpentinite fertilization. European Journal of Forest Research 134: 981-990. doi: 10.1007/s10342-015-0903-1

Carnol M, Bazgir M (2013). Nutrient return to the forest floor through litter and throughfall under 7 forest species after conversion from Norway spruce. Forest Ecology and Management
309: 66-75. - doi: 10.1016/j.foreco.2013.04.008 Castle SC, Neff JC (2009). Plant response to nutrient availability across variable bedrock geologies. Ecosystems 12: 101-113. - doi: 10.1007/s1002 1-008-9210-8

Černý K, Pešková V, Soukup F, Havrdová L, Strnadová V, Zahradník D, Hrabetová M (2016). Gemmamyces bud blight of Picea pungens: a sudden disease outbreak in Central Europe. Plant Pathology 65 (8): 1267-1278. - doi: 10.1111/ ppa.12513

Grodzki W (2009). Entomofauna of dying young spruces Picea abies (L.) Karst. in the area after forest decline in the Izerskie Mountains. Folia Forestalia Polonica, Series A 51 (2): 161-170.

Hagen-Thorn A, Callesen I, Armolaitis K, Nihlgård B (2004). The impact of six European tree species on the chemistry of mineral topsoil in forest plantations on former agricultural land. Forest Ecology and Management 195: 373-384. doi: 10.1016/j.foreco.2004.02.036

Holm S (1979). A simple sequentially rejective multiple test procedure. Scandinavian Journal of Statistics 6: 65-70. [online] URL: http:// www.jstor.org/stable/4615733

Kacálek D, Špulák O, Dušek D, Kuneš I, Balcar V (2013). Species-specific properties of forest floor under mountain conditions. Austrian Journal of Forest Science 130 (1): 45-59. [online] URL: http://www.forestscience.at/fileadmin/us er_upload/CB1301_Kacalek1.pdf

Kantor P (1989). Meliorační účinky porostu náhradních drevin [Ameliorative effects of substitute forest trees]. Lesnictví 35: 1047-1066. [in czech]

Kellomäki S, Strandman H, Heinonen T, Asikainen A, Venäläinen A, Peltola $H$ (2018). Temporal and spatial change in diameter growth of boreal Scots pine, Norway spruce, and birch under recent-generation (CMIP5) global climate model projections for the 21st century. Forests 9 (3): 118. - doi: 10.3390/f9030118

Kranabetter JM, Banner A (2000). Selected biological and chemical properties of forest floors across bedrock types on the north coast of British Columbia. Canadian Journal of Forest Research 30 (6): 971-981. - doi: 10.1139/xoo-018

Kranabetter JM, Coates KD (2004). Ten-year postharvest effects of silviculture systems on soil-resource availability and conifer nutrition in a northern temperate forest. Canadian Journal of Forest Research 34 (4): 800-809. - doi: 10.1139/x03-244

Kuneš I, Balcar V, Vykypelová E, Zadina J, Šedlbauerová J, Zahradník D (2007). Vliv jamkové a pomístné povrchové aplikace dolomitického vápence na množství a chemické složení biomasy smrku ztepilého $v$ Jizerských horách [Effects of planting hole application or spot surface application of finely ground dolomitic limestone on amount and chemical composition of biomass of Norway spruce in the Jizerské hory Mts.]. Reports of Forestry Research Zprávy lesnického výzkumu 52 (4): 316-327. [in Czech]

Lazarus BE, Schaberg PG, Hawley GJ, DeHayes DH (2006). Landscape-scale spatial patterns of winter injury to red spruce foliage in a year of heavy region-wide injury. Canadian Journal of Forest Research 36 (1): 142-152. - doi: 10.1139/xo 5-236
Lê S, Josse J, Husson F (2008). FactoMineR: an R package for multivariate analysis. Journal of Statistical Software 25 (1): 1-18. - doi: 10.18637/ jss.v025.io1

Lomský B, Srámek V, Novotny R (2012). Changes in the air pollution load in the Jizera Mts.: effects on the health status and mineral nutrition of the young Norway spruce stands. European Journal of Forest Research 131: 757-771. - doi: 10.1007/s10342-011-0549-6

Mallik AU, Hossain MK, Lamb EG (2008). Species and spacing effects of northern conifers on forest productivity and soil chemistry in a 50-yearold common garden experiment. Journal of Forestry 106 (2): 83-90. [online] URL: http:// academic.oup.com/jof/article/106/2/83/4734838 Mason WL (2014). Long-term development of nursing mixtures of Sitka spruce and larch species in an experiment in northern Scotland. Forest Systems 23 (3): 590-597. - doi: 10.5424/fs/ 2014233-06084

Materna J (1989). Air pollution and forestry in Czechoslovakia. Environmental Monitoring and Assessment 12 (3): 227-235. - doi: 10.1007/BFo03 94802

Matsushima M, Choi WJ, Chang SX (2012). White spruce foliar $\delta^{13} \mathrm{C}$ and $\delta^{15} \mathrm{~N}$ indicate changed soil $\mathrm{N}$ availability by understory removal and $\mathrm{N}$ fertilization in a 13-year-old boreal plantation. Plant and Soil 361: 375-384. - doi: 10.1007/s11104012-1254-z

Mehlich A (1984). Mehlich 3 soil test extractant: a modification of Mehlich 2 extractant. Communications in Soil Science and Plant Analysis 15: 1409-1416. - doi: 10.1080/00103628409367568

Mellert KH, Göttlein A (2012). Comparison of new foliar nutrient thresholds derived from van den Burg's literature compilation with established central European references. European Journal of Forest Research 131: 1461-1472. - doi: 10.1007/s10342-012-0615-8

Mellert KH, Prietzel J, Straussberger R, Rehfuess KE (2004). Long-term nutritional trends of conifer stands in Europe: results from the RECOGNITION project. European Journal of Forest Research 123: 305-319. - doi: 10.1007/s10342-0040044-4

Nárovec V, Šach F (1994). Meliorace lesních pud pomocí bazických silikátových hornin [Amelioration of forest soils by means of silicate rock meals]. Reports of Forestry Research - Zprávy lesnického výzkumu 39 (3): 17-20. [in Czech]

Nemeček J, Macků J, Vokoun J, Vavríček D, Novák P (2001). Taxonomický klasifikační systém pud Ceské republiky [Taxonomic soil classification system of the Czech Republic]. CZU and vúMOP, Prague, Czech Republic, pp. 78. [in Czech]

Nitschke CR, Waeber PO, Klaassen JW, Dordel J, Innes JL, Aponte C (2017). Nutrient uptake and use efficiency in co-occurring plants along a disturbance and nutrient availability gradient in the boreal forests of the southwest Yukon, Canada. Journal of Vegetation Science 28: 6981. - doi: 10.1111/jvs.12468

Novotny R, Lomský B, Srámek V (2013). The health and nutritional status of Norway spruce stands in the Krušné hory Mts. 15 years subsequent to the extreme winter of 1995/96. Journal of Forest Science 59 (9): 359-369. [online] URL: http://www.researchgate.net/publication/ 
259081342

Novotny R, Buriánek V, Hunová I, Skorepová I, Zapletal M, Lomský B (2017). Nitrogen deposition and its impact on forest ecosystems in the Czech Republic - change in soil chemistry and ground vegetation. iForest - Biogeosciences and Forestry 10 (1): 48-54. - doi: 10.3832/ifor184 7-009

Oulehle F, Evans CD, Hofmeister J, Krejci R, Tahovska K, Persson T, Cudlin P, Hruska J (2011). Major changes in forest carbon and nitrogen cycling caused by declining sulphur deposition. Global Change Biology 17: 3115-3129. - doi: 10.1111/j.1365-2486.2011.02468.x

Perry DA, Oren R, Hart SC (1995). Forest ecosystems. John Hopkins University Press, London, UK, pp. 632.

Power H, Schneider R, Berninger F (2014). Understanding changes in black (Picea mariana) and white spruce (Picea glauca) foliage biomass and leaf area characteristics. Trees 28: 345-357. - doi: 10.1007/s00468-013-0953-2

Prescott CE, Vesterdal L, Pratt J, Venner KH, De Montigny LM, Trofymov JA (2000). Nutrient concentrations and nitrogen mineralization in forest floors of single species conifer plantations in coastal British Columbia. Canadian Journal of Forest Research 30 (9): 1341-1352. doi: 10.1139/x00-062

Preston CM, Bhatti JS, Norris CE (2014). Chemical quality of aboveground litter inputs for jack pine and black spruce stands along the Canadian Boreal Forest Transect Case Study. Écoscience 21 (3-4): 202-216. - doi: 10.2980/21-(3-4)3690

R Core Team (2017). R: a language and environment for statistical computing. R Foundation for Statistical Computing, Vienna, Austria. [online] URL: http://www.R-project.org/
Rautio P, Fürst A, Stefan K, Raitio $H$, Bartels $U$ (2016). Part XII: Sampling and analysis of needles and leaves. In: "Manual on Methods and Criteria for Harmonized Sampling, Assessment, Monitoring and Analysis of the Effects of Air Pollution on Forests" (UNECE ICP Forests Programme Co-ordinating Centre ed). Thünen Institute of Forest Ecosystems, Eberswalde, Germany, pp. 19. [online] URL: http://www.icpforests.org/pdf/manual/2016/ICP_Manual_2017 01 part12.pdf

Ribbons RR, Levy-Booth DJ, Masse J, Grayston SJ, McDonald MA, Vesterdal L, Prescott CE (2016). Linking microbial communities, functional genes and nitrogen-cycling processes in forest floors under four tree species. Soil Biology and Biochemistry 103: 181-191. - doi: 10.1016/ j.soilbio.2016.07.024

Sáňka M, Materna J (2004). Indikátory kvality zemedelských a lesních pud CR [Quality indicators of the agriculture and forest soils of the Czech Republic]. Ministerstvo životního prostredí, Praha, Czech Republic, pp. 84. [in Czech] Slodičák $M$, Balcar $V$, Bednárová $E$, Boruvka L, Fadrhonsová V, Jurásek A, Hadaš $P$, Kacálek D, Kantor P, Kulasová A, Kulhavy J, Leube F, Lomský B, Matejka K, Mauer O, Navrátil P, Nárovec V, Novák J, Ostrovsky J, Palátová E, Podrázsky V, Rychnovská A, Ričár L, Skorupski M, Smejkal J, Souček J, Stoklasa M, Vacek S (2009). Lesnické hospodarení v Jizerských horách [Forestry management in the Jizerské hory Mts. ]. Lesnická práce, Kostelec nad Černými lesy, Czech Republic, pp. 232. [in Czech]

Slodičák M, Balcar V, Novák J, Boruvka L, Derco D, Detu E, Fadrhonsová V, Fiala P, Hadaš P, Hajnala $M$, Havránek F, Hellebrandová K, Humplík J, Hynek V, Jarsky V, Jurásek A, Kacálek D, Kanák J, Kmínek A, Kobliha J, Kula E, Kulhavy J,
Lachmanová Z, Lehner J, Lehnerová L, Lehečka J, Leugner J, Lomský B, Martincová J, Matejka K, Mauer O, Menšík L, Mutínsky V, Nárovcová J, Nárovec V, Navrátil P, Novotny R, Novy L, Penička L, Pospíšil J, Pulkrab K, Skoblík J, Sloup M, Smejkal J, Sychrava J, Vortelová L, Vyslyšel K (2008). Lesnické hospodarení v Krušných horách. [Forestry management in the Krušné hory Mts.]. LCR s.p., Hradec Králové, Czech Republic, pp. 480. [in Czech]

Srámek V, Lomský B, Novotný R (2009). Hodnocení obsahu a zásoby živin v lesních porostech literární prehled. [Content of nutrients in forest stands - review]. Reports of Forestry Research Zprávy lesnického výzkumu 51 (4): 307-315. [in Czech]

Thomas KD, Prescott CE (2000). Nitrogen availability in forest floors of three tree species on the same site: the role of litter quality. Canadian Journal of Forest Research 30 (11): 16981706. - doi: 10.1139/xo0-101

Vu VQ (2011). Ggbiplot. A tool for visualizing the results of PCA. Software, Web site. [online] URL: http://www.vince.vu/software/\#ggbiplot Zbíral J (2001). Porovnání extrakčních postupu pro stanovení základních živin $\mathrm{v}$ pudách $\mathrm{CR}$. [Comparison of the extraction methods for assessment of the basic nutrients in soils of the Czech Republic]. ÚKZÚZ, Brno, Czech Republic, pp. 205. [in Czech]

\section{Supplementary Material}

Tab. S1 - Properties of forest floor and soil horizons (mean and standard deviation).

Link: Spulak_2731@supplo01.pdf 